\title{
Statistical analysis of the design procedure used in reinforced concrete pipes
}

\section{Análise estatística do modelo de cálculo estrutural utilizado em tubos circulares de concreto armado}
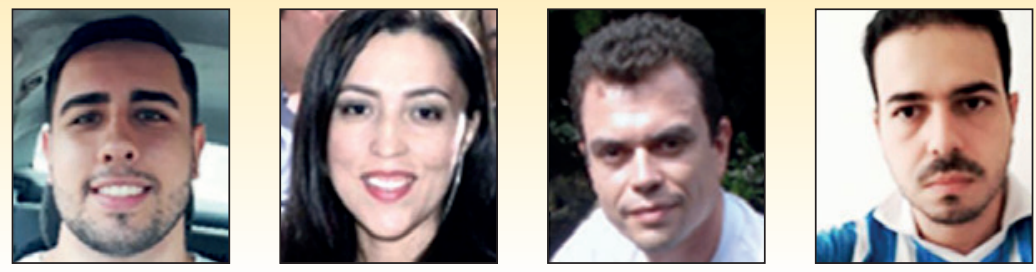

F. M. FLORESTA a

frankufss@gmail.com https://orcid.org/0000-0002-7692-6163

C. S. VIEIRA b

milavieira@gmail.com https://orcid.org/0000-0002-5371-191X

L. A. MENDES a

lamendes@ufs.br https://orcid.org/0000-0002-8202-7623

D. L. N. F. AMORIM a

david.amorim@ufs.br

https://orcid.org/0000-0002-9233-3114

\begin{abstract}
Structural design procedures are based on simplified hypotheses that attempt to approximate the actual behaviour. Depending on the adopted hypothesis, the design procedure may not satisfactorily describe the structural actual behaviour. Such condition occurs in the design of reinforced concrete pipes, where there are uncertainties related especially on the internal forces and the installation type of the pipe. Moreover, the main design hypothesis is that the cross section is plane and perpendicular to the deformed axis. Based on materials resistance principles it is known that this hypothesis is unsatisfactory to pipes with aspect ratio lower than ten. Note that the commercial reinforced concrete pipes usually present aspect ratio well below ten. In the light of the foregoing, the main objective of this paper is to analyse the accuracy of the design procedure for reinforced concrete pipes. Therefore, statistical processes were used to compare design values with experimental results. The comparisons in this paper showed that the design procedure results in oversized pipes.
\end{abstract}

Keywords: reinforced concrete pipes, design procedure, statistical analysis.

\section{Resumo}

Os modelos de cálculo estrutural são baseados em hipóteses simplificadoras, que visam aproximar-se do comportamento real. A depender das hipóteses adotadas, o modelo de cálculo pode não descrever com exatidão o comportamento real da estrutura em estudo. Tal condição ocorre no projeto de tubos de concreto armado, onde há incertezas especialmente na determinação dos esforços internos e no tipo de instalação do tubo. Além disso, a principal hipótese simplificadora no projeto de tubos de concreto armado é que a seção transversal permanece plana e perpendicular ao eixo deformado. Com base nos princípios da resistência dos materiais, sabe-se que esta hipótese não é satisfatória para tubos com relação raio/altura da seção transversal inferior a dez. Nota-se que os tubos comerciais usualmente apresentam valores bem abaixo de dez para esta relação. Desta forma, este trabalho tem como objetivo a análise da acurácia do modelo de cálculo para tubos de concreto armado. Para tanto, processos estatísticos foram utilizados para confrontar os valores de projeto obtidos no modelo de cálculo com resultados experimentais. As comparações realizadas neste trabalho mostram que o modelo de cálculo utilizado no dimensionamento de tubos de concreto armado resulta em valores exageradamente a favor da segurança.

Palavras-chave: tubos de concreto armado, modelo de cálculo, análise estatística.

Universidade Federal de Sergipe, Centro de Ciências Exatas e Tecnologia, Departamento de Engenharia Civil, São Cristóvão, SE, Brasil;

Universidade Federal de Alagoas, Centro de Tecnologia, Maceió, AL, Brasil.

Received: 06 Aug 2018 • Accepted: 12 Jun 2019 • Available Online: 23 Jan 2020

This is an open-access article distributed under the terms of the Creative Commons Attribution License 


\section{Introduction}

Usually, structures are designed by deterministic calculation, where the resistance values are decreased and load values are increased by coefficients. Such coefficients come from a semi-probabilistic process named limit state method. Therefore, the code regulations bring different values for the coefficients associated to each material and its production process. Regarding loads, the coefficients are related to the nature of the actions. Such values take into account the uncertainties associated to the randomness of the materials resistance and the applied loads. Still, the adopted design process presents simplifications and approximations that may not describe accurately the actual structural behaviour [1].

The main issue of the reinforced concrete pipes design is the calculation of the internal forces. Besides the uncertainty associated to loads and materials, despite the possible rigor in the fabrication process, there are still uncertainties associated with the form of pipe installation [2]. In order to minimise the uncertainties associated to the design of reinforced concrete pipes, the use of Marston-Spangler's procedure is suggested [3], where the vertical loads are calculated by a standardised three-edge-bearing test, according to NBR 8890 [4], of a pipe with a nominal diameter DN and effective length $L$ as shown in Figure 1. The relation between the experimental force $(P)$ and the acting load $(q)$ is obtained by using an equivalence factor $\left(\alpha_{\text {eq }}\right)$ that depends on the form of pipe installation [2].

$P=\frac{q}{\alpha_{e q}}$

The collapse and critical cracking of a pipe can be determined based on the three-edge-bearing test (Figure 1). Such procedure is used as an acceptability criterion of reinforced concrete pipes by NBR 8890 [4], which is not applicable to design.

According to El Debs [2], the design of reinforced concrete pipes must
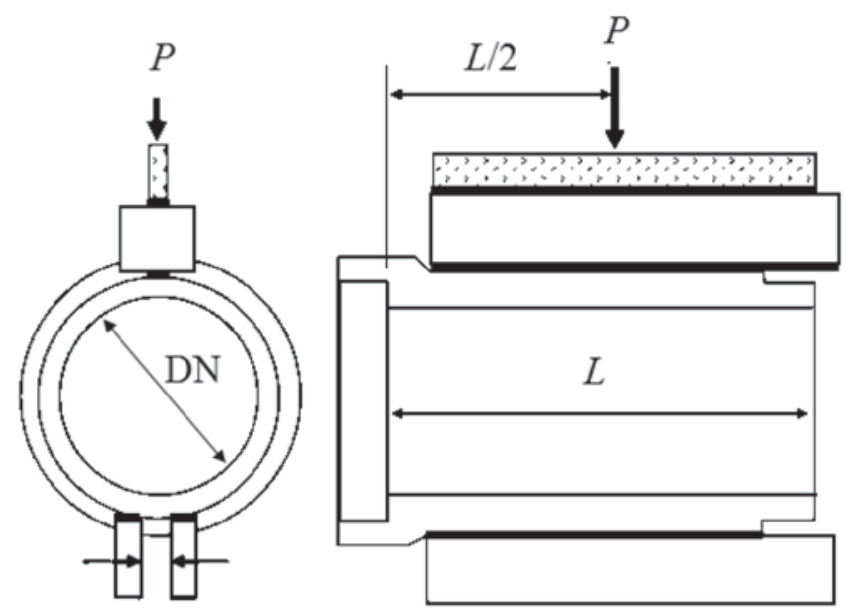

$\mathrm{DN} / 10$

(minimum of $20 \mathrm{~mm}$ )

\section{Figure 1}

Three-edge-bearing test (after [4])

be based on NBR 6118 [5]. Therewith, the walls of the pipe are designed as one-way slabs. Thus, the main assumption to the design is that the elements under flexure behave according to the Euler-Bernoulli hypothesis (the cross section is plane and perpendicular to the deformed axis). Such consideration results in a linear strain distribution along the cross section depth. On the other hand, based on materials resistance it is well known that the stress or strain distribution along the cross section depth of a circular element composed by a homogeneous material that behaves according to the Hooke's law is hyperbolic [6]. Therefore, there is an uncertainty level associated to the design process, since the walls of the pipe can be understood as circular elements. This type of uncertainty is called model uncertainty [7].

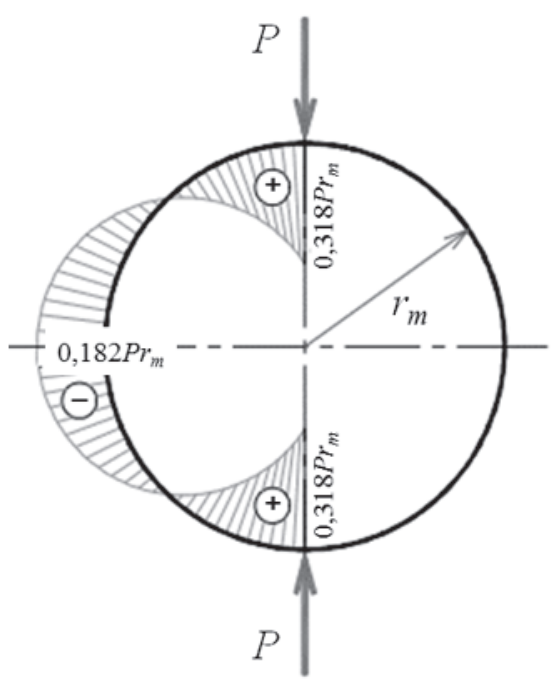

Bending moment

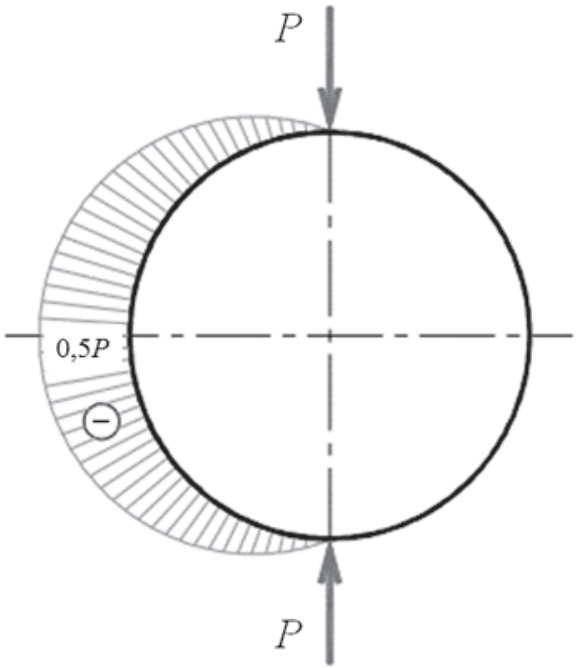

Axial force

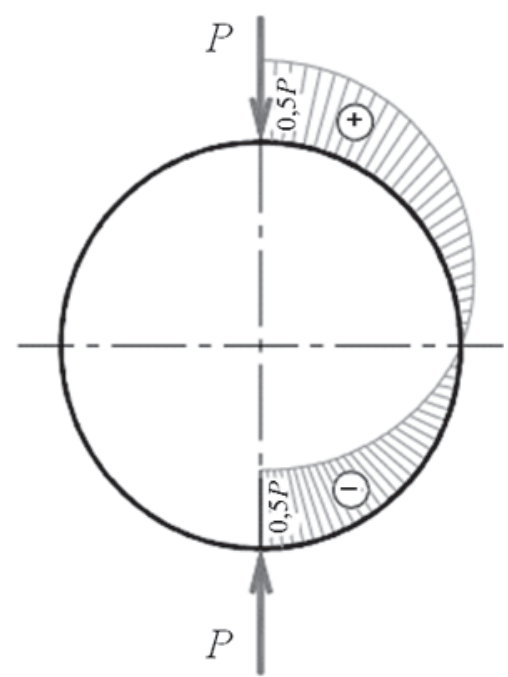

Shear force

Figure 2

Diagram of internal forces (after [2]) 

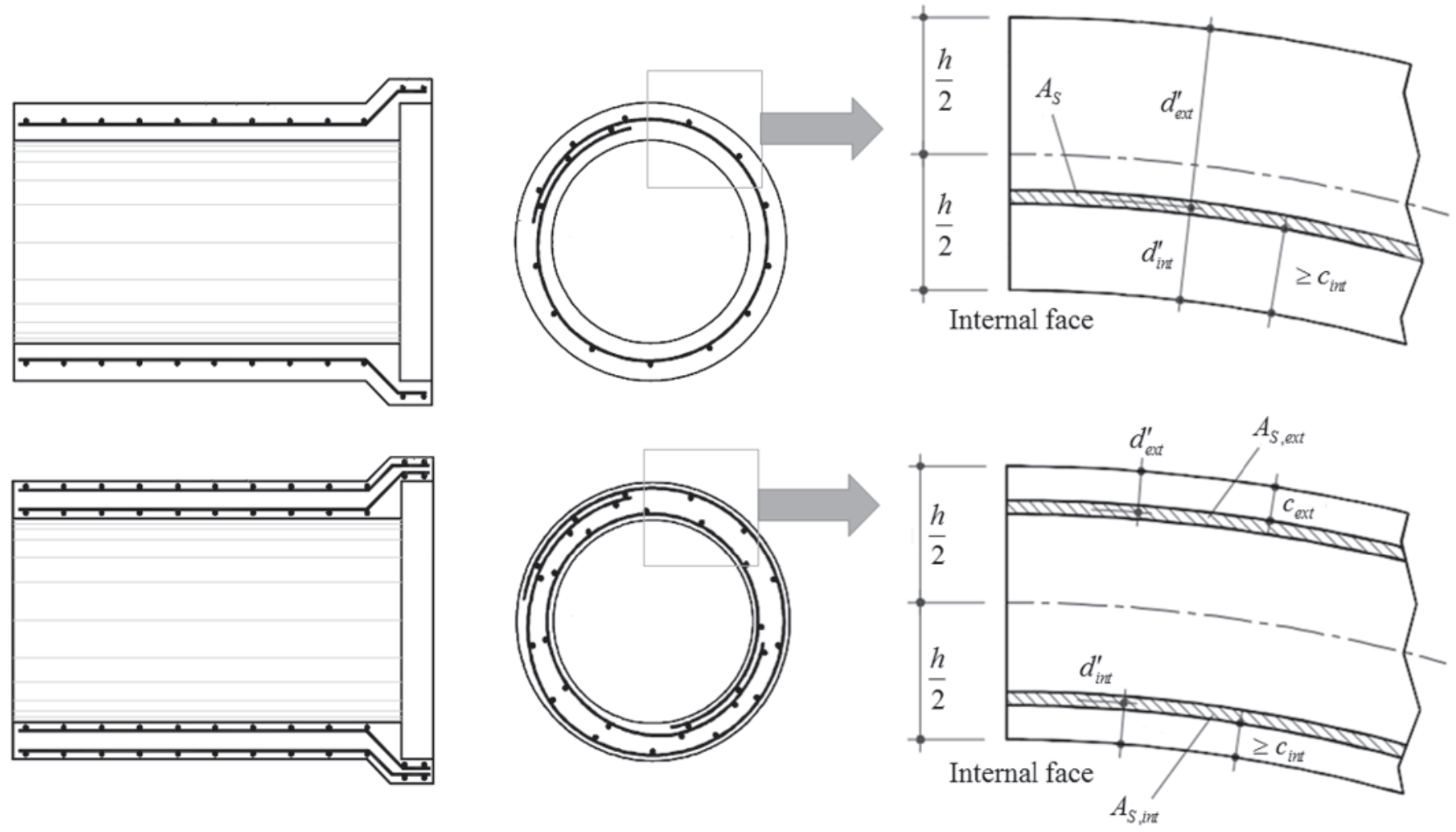

\section{Figure 3}

Reinforcement scheme (after [4])

In the light of the foregoing, this paper aims to evaluate the accuracy of the design process applied to reinforced concrete pipes. Therefore, statistical processes are used to compare the design values with the experiments presented by Silva [8] and Silva et al. [9].

The model uncertainty is not quantified in this paper because Silva [8] and Silva et al. [9] do not present sufficient data to dissociate the model uncertainty to the other ones, as the ones associated to materials and to the experimental procedure itself. Thus, resistance characteristic values are used to the materials to ensure feasibility of the accuracy evaluation of the design model in comparison with experiments.

Concerning other researches on the theme of this paper, Silva et al. [10] presented a structural reliability study of the service limit state of reinforced concrete pipes. On the other hand, Figueiredo et al. [11] and Oliveira et al. [12] carried out experimental studies in concrete pipes reinforced only with steel fibres.

According to Silva et al. [10], the equations presented by NBR 6118 [5] to the cracking service limit state result in different values of the reliability index. Despite the importance of the contribution of Silva et al. [10], there is no similar study to the one presented in this paper.

\section{Internal forces in the three-edge-bearing test}

Consider a compressed ring based on the three-edge-bearing test (Figure 1 ), where the average radius $\left(r_{m}\right)$ of the wall of the pipe defines its axis. Thus, the diagrams of internal forces are indicated in Figure 2. It can be observed that a bending moment equal to $0,318 \mathrm{Pr}_{\mathrm{m}}$ acts at the crown (top of the pipe) and both bending moment and axial force equal to $0,182 \mathrm{Pr}_{\mathrm{m}}$ and $0,5 \mathrm{P}$ occur at the flank. The mathematical model of the compressed ring (Figure 2) considers that a concentrated force $(P)$ acts at the base of the pipe. However, the base of the pipe is supported in two edges in the three-edge-bearing test (Figure 1). Then, such condition implies in a reduction of the bending moment in the crown to $0,293 \mathrm{Pr}_{\mathrm{m}}$ [2]. The reinforcement set-up (Figure 3 ) must comply with the internal forces acting in the crown and the flank. Usually, pipes with nominal diameter lower than $1000 \mathrm{~mm}$ present simple reinforcement $\left(A_{s}\right)$, otherwise a doubly reinforcement $\left(A_{s, \text { int }}\right)$ and $\left.A_{s, \text { ext }}\right)$ is used, as sketched in Figure 3. The reinforcement is composed by a welded wire mesh and the external $\left(\mathrm{c}_{\text {ext }}\right)$ and internal $\left(\mathrm{c}_{\text {int }}\right)$ concrete covers are recommended by El Debs [2]. Based on the concrete covers, the distance between the geometric centre of each reinforcement to the internal $\left(d^{\prime}{ }_{\text {int }}\right)$ and external $\left(d^{\prime}{ }_{\text {ext }}\right)$ faces of the pipe are then calculated.

\section{Three-edge-bearing test}

The experiments carried out by Silva [8] and Silva et al. [9] were developed from a sample of 16 pipes with DN $800 \mathrm{~mm}$ and a sample of 16 pipes with DN $1200 \mathrm{~mm}$. The reinforcement of all pipes are composed by a welded wire mesh of CA-60 steel, which the elasticity modulus is $210 \mathrm{GPa}$. Further information about thickness, 
Table 1

Reinforced concrete pipes data [8]

\begin{tabular}{ccc}
\hline $\begin{array}{c}\text { DN } \\
{[\mathrm{mm}]}\end{array}$ & $\mathbf{8 0 0}$ & 1200 \\
\hline $\begin{array}{c}\text { Thickness }(\mathrm{h}) \\
{[\mathrm{cm}]}\end{array}$ & 7.2 & 11.0 \\
Reinforcement & $A_{S}=3,96 \mathrm{~cm}^{2} / \mathrm{m}$ & $\left\{\begin{array}{l}A_{S, \text { ext }}=1,96 \mathrm{~cm}^{2} / \mathrm{m} \\
A_{S, \text { int }}=3,96 \mathrm{~cm}^{2} / \mathrm{m}\end{array}\right.$ \\
$\begin{array}{c}\text { Diameters of } \\
\text { the bars }\end{array}$ & $\left\{\begin{array}{l}\phi_{\text {ext }}=5,0 \mathrm{~mm} \\
\phi_{\text {int }}=7,1 \mathrm{~mm}\end{array}\right.$ & $\left\{\begin{array}{l}\phi_{\text {ext }}=5,0 \mathrm{~mm} \\
\phi_{\text {int }}=7,1 \mathrm{~mm}\end{array}\right.$ \\
$\mathrm{d}^{\prime}{ }_{\text {ext }}$ & $4.26 \mathrm{~cm}$ & $2.45 \mathrm{~cm}$ \\
$\mathrm{~d}_{\text {int }}$ & $2.94 \mathrm{~cm}$ & $4.16 \mathrm{~cm}$ \\
$\mathrm{f}_{\mathrm{ck}}$ & $30.28 \mathrm{MPa}$ & $32.20 \mathrm{MPa}$ \\
\hline
\end{tabular}

reinforcement and its location, diameters of the steel wire and characteristic compressive strength resistance of the concrete $\left(f_{c k}\right)$ are depicted in Table 1.

The experimental results are shown in force-displacement graphics, with an aspect similar to the one exposed in Figure $4[8,9]$. Therewith, the values of maximum or ultimate force $\left(P_{\text {ult }}\right)$ and cracking or service force $\left(P_{\text {ser }}\right)$ are obtained from the experimental response of each pipe.

Analytically, the maximum or ultimate force $\left(P_{\text {ult }}\right)$ is obtained by the ultimate condition (ultimate limit state) of the cross section of the crown or the flank of the pipe. The cracking or service force $\left(P_{\text {ser }}\right)$ is calculated by the crack opening limit state. The design models of this step are described as follows.

\section{Ultimate and service limit states}

The design in ultimate limit state of reinforced concrete structural elements submitted to bending with or without axial force is widely known in the technical literature [13-18].

Consider a reinforced concrete structural element subjected to a

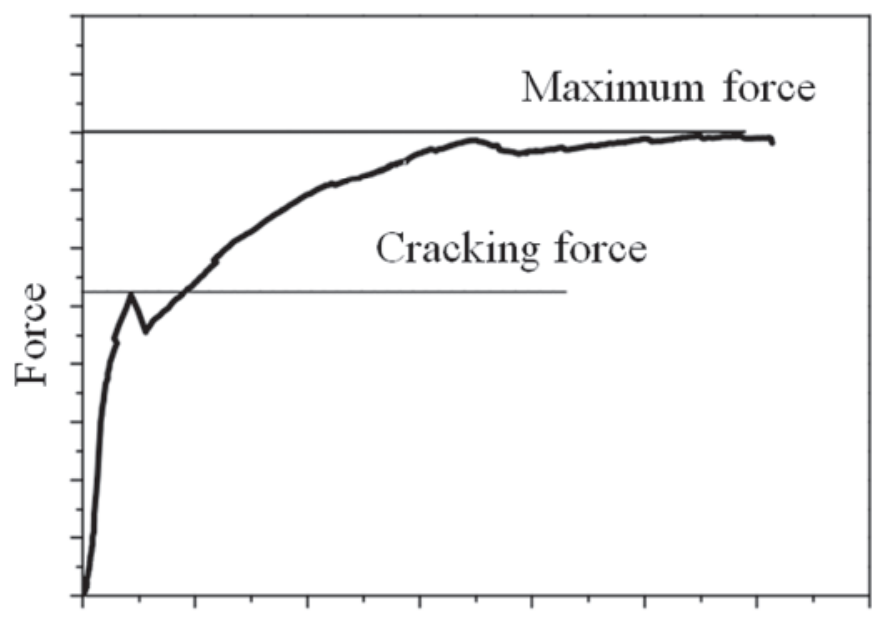

Displacement

Figure 4

Typical response of reinforced concrete pipes submitted to the three-edge-bearing test [8]

bending moment $\left(M_{d}\right)$ and an axial compression force $\left(N_{d}\right)$. Then, the cross section of such element must resist to $M_{d}$ and $N_{d^{\prime}}$. According to the design process employed on reinforced concrete tubes by NBR 8890 [4], consider a rectangular cross section with base $\left(b_{w}\right)$ and height $(h)$ defined in Figure 5.

Assuming that the Euler-Bernoulli hypothesis is valid, the strain distribution in the cross section is linear (Figure 5). From the most compressed concrete fibre $\left(\varepsilon_{\mathrm{c}}\right)$ is defined the location of the neutral axis $(\mathrm{x})$. For the design process, it is supposed that the concrete tensile resistance is negligible. Thus, by obeying the concrete covers [5], a reinforcement is located in the traction zone. The distance between the reinforcement geometric centre and the most compressed fibre is the effective height (d).

The strains of the reinforcements in tension and in compression can be calculated by (Figure 5):

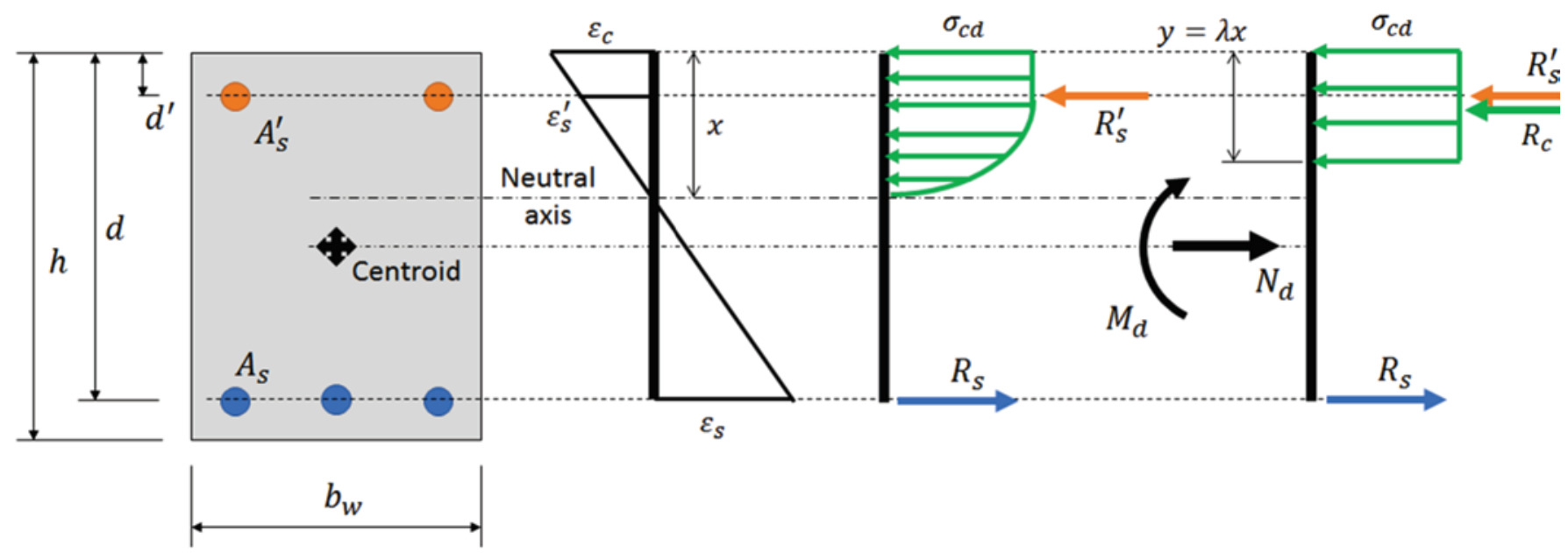

Figure 5

Rectangular cross section submitted to an axial force and a bending moment 
$\frac{\varepsilon_{C}}{x}=\frac{\varepsilon_{S}}{x-d^{\prime}}=\frac{\varepsilon_{S}}{d-x}$

being $\varepsilon_{\mathrm{S}}$ and $\varepsilon_{\mathrm{S}}^{\prime}$ the strains of the reinforcements in tension and in compression, respectively.

By defining $\beta_{x}=x / d$ as the relative depth of the neutral axis, equation (2) may be written as follows:

$\frac{\varepsilon_{C}}{\beta_{x}}=\frac{\varepsilon_{S}}{\beta_{x}-\frac{d^{\prime}}{d}}=\frac{\varepsilon_{S}}{1-\beta_{x}}$

For a certain load level, the reinforcements in compression and in tension present stresses $\sigma_{s}^{\prime}$ and $\sigma_{s}$, respectively. Therewith, the reaction forces in the reinforcements in compression $\left(R_{S}^{\prime}=A_{S}^{\prime} \sigma_{S}^{\prime}\right)$ and in tension $\left(R_{S}=A_{S} \sigma_{S}\right)$ are then defined.

The compression stress distribution is considered as a rectangleparabola diagram (Figure 5). The parabolic segment presents maximum stress for the initial plastic strain $\left(\varepsilon_{0}\right)$. Assuming that there is no increase of stress for strains greater that $\varepsilon_{0}$ and lower than the ultimate concrete strain $\left(\varepsilon_{\text {cu }}\right)$. The rectangle-parabola diagram can be replaced by an equivalent rectangular diagram with depth $y=\lambda x$ (Figure 5 ), where $\lambda$ is given by the concrete class. The design compression stress in concrete $\left(\sigma_{c d}=\alpha_{c} f_{c d}\right)$ is given by the product between the compression reduction parameter $\left(\alpha_{c}\right)$ and the design compressive strength resistance of the concrete $\left(f_{c d}\right)$. Thus, the reaction force in concrete is obtained $\left(R_{c}=b_{w} y \sigma_{c d}\right)$.

Ergo, the following expressions are obtained from the cross section equilibrium (Figure 5):

$N_{d}=b_{w} d \lambda \beta_{x} \alpha_{c} f_{c d}+A_{S}^{\prime} \sigma_{S}^{\prime}-A_{S} \sigma_{S}$

$M_{d}=b_{w} d^{2} \lambda \beta_{x} \alpha_{c} f_{c d}\left(1-\frac{\lambda \beta_{x}}{2}\right)+A_{S}^{\prime} \sigma_{S}^{\prime}\left(d-d^{\prime}\right)$

According to NBR 6118 [5], $\varepsilon_{0}=2 \%, \varepsilon_{\text {cu }}=3,5 \%, \lambda=0,8$ and $\alpha_{c}=0,85$ for concretes with characteristic compressive strength resistance of the concrete $\left(f_{c k}\right)$ lower or equal to 50MPa. Thus, the equilibrium equations can be rewritten as:

$N_{d}=0,68 b_{w} d \beta_{x} f_{c d}+A_{S}^{\prime} \sigma_{S}^{\prime}-A_{S} \sigma_{S}$

$M_{d}=0,68 b_{w} d^{2} \beta_{x} f_{c d}\left(1-0,4 \beta_{x}\right)+A_{S}^{\prime} \sigma_{S}^{\prime}\left(d-d^{\prime}\right)$

The equilibrium equations (6) and (7) must be used for the flank of the pipe. To consider the crown, the axial force must be nil i.e. $\mathrm{N}_{\mathrm{d}}=0$. Therefore, only equation (6) is modified:

$0,68 b_{w} d \beta_{x} f_{c d}+A_{S}^{\prime} \sigma_{S}^{\prime}-A_{S} \sigma_{S}=0$

Therewith, reinforced concrete pipes are designed considering equations (3), (6) and (7) for the flank and equations (3), (7) and (8) for the crown.

The service condition considered in the design of pipes is the crack opening limit state. According to NBR 8890 [4], such service limit state is achieved if the crack opening $(w)$ is lower than $0.25 \mathrm{~mm}$.

$w=$ minimum of: $\left\{\begin{array}{c}\frac{\phi_{i}}{12,5 \eta_{i}} \frac{\sigma_{S i}}{E_{S i}} \frac{3 \sigma_{S i}}{f_{c t, m}} \\ \frac{\phi_{i}}{12,5 \eta_{i}} \frac{\sigma_{S i}}{E_{S i}}\left(\frac{4}{\rho_{r i}}+45\right)\end{array}\right.$ being:

$\varphi_{\mathrm{i}}$ : the wire diameter of the reinforcing welded mesh;

$\eta_{i}$ : adhesion coefficient of the reinforcing wire mesh in tension (adopted as 2.25, since the wires produced in Brazil are ribbed);

$\mathrm{E}_{\mathrm{Si}}$ : steel elasticity modulus;

$f_{c t, m}=0,3 f_{c k}^{2 / 3}$ : average tension resistance of the concrete;

$\rho_{\mathrm{ri}}$ : geometric rate of the reinforcement wire with respect to the enveloping area $\left(A_{c r, i}=\left(15 \varphi_{i}\right)^{2}\right)$;

$\sigma_{\mathrm{Si}}$ : tensile stress in the reinforcement mesh in tension, which can be calculated by:

$\sigma_{S i}=\frac{M_{d}}{A_{S} 0,9 d}$

\section{Analysis}

\subsection{Design model for reinforced concrete pipes}

In order to evaluate the accuracy of the design procedure of reinforced concrete pipes, the compatibility and equilibrium equations for the flank and the crown were applied without the safety coefficients. Then, for the ultimate limit state the design stresses $\left(M_{d}\right.$ and $\left.N_{d}\right)$ are now acting stresses $\left(M_{k}\right.$ and $\left.N_{k}\right)$, the design resistances $f_{c d}$ and $\mathrm{f}_{\mathrm{yd}}$ are replaced by $\mathrm{f}_{\mathrm{ck}}$ and $\mathrm{f}_{\mathrm{yk}}$, respectively.

Therefore, the equilibrium equations for the flank are rewritten as:

$N_{k}=0,5 P_{u l t}=0,68 b_{w} d \beta_{x} f_{c k}+A_{S}^{\prime} \sigma_{S}^{\prime}-A_{S} \sigma_{S}$

$M_{k}=0,182 P_{u l t} r_{m}=0,68 b_{w} d^{2} \beta_{x} f_{c k}\left(1-0,4 \beta_{\chi}\right)+A_{S}^{\prime} \sigma_{S}^{\prime}\left(d-d^{\prime}\right)$

For the crown, the equilibrium equations are:

$0,68 b_{w} d \beta_{x} f_{c k}+A_{S}^{\prime} \sigma_{S}^{\prime}-A_{S} \sigma_{S}=0$

$M_{k}=0,293 P_{u l t} r_{m}=0,68 b_{w} d^{2} \beta_{x} f_{c k}\left(1-0,4 \beta_{x}\right)+A_{S}^{\prime} \sigma_{S}^{\prime}\left(d-d^{\prime}\right)$

Therewith, the ultimate force $\left(P_{\text {ult }}\right)$ is obtained by solving simultaneously equations (11) through (14).

Regarding the service limit state, the greater cracking level occurs in the crown. Therefore, equation (10) is inserted in equation (9), resulting the following relation to determine the service force $\left(P_{\text {ser }}\right)$ :

$P_{\text {ser }}=$ maximum of: $\left\{\begin{array}{l}\frac{A_{S} 0,9 d}{0,293 r_{m}} \sqrt{\frac{12,5 \eta_{i} f_{c t, m} E_{S i}}{3 \phi_{i}} w} \\ \frac{12,5 \eta_{i} E_{S i} A_{S} 0,9 d}{0,293 r_{m} \phi_{i}\left(\frac{4}{\rho_{r i}}+45\right)} w\end{array}\right.$

The calculated values of $\mathrm{P}_{\text {ult }}$ and $\mathrm{P}_{\text {ser }}$ are here called design values (DV).

\subsection{Statistical analysis}

Basic statistics for the experiments of Silva [8] and Silva et al. [9] are determined in this paper, such as mean and standard deviation of the ultimate force $\left(P_{\text {ult }}\right)$ and service force $\left(P_{\text {ser }}\right)$ for both samples (DN $800 \mathrm{~mm}$ and DN 1200mm) with 16 elements each. From such data, it is possible to define confidence intervals $(\mathrm{Cl})$ for the means of $\mathrm{P}_{\text {ult }}$ and $\mathrm{P}_{\text {ser }}$. This procedure allows to evaluate if the design value 
is contained in the $\mathrm{Cl}$, which was determined from experiments. The $\mathrm{Cl}$ around the mean values are obtained for a confidence level $(1-\alpha)$. Since the compressive strength resistance of the concrete follows a normal distribution $[13,15]$ and the variance of the population is not known, the estimator $\mathrm{T}$ is adopted to build the $\mathrm{Cl}$, that follows the Student $\mathrm{t}$ distribution and, according to Hammer et al. [20], is given by:

$$
T=\frac{\bar{x}-\mu}{\frac{S}{\sqrt{n}}}
$$

being:

$T$ : random variable with Studen $t$ distribution and $(n-1)$ degrees of freedom;

$\bar{x}$ : sample mean;

$\mu$ : population mean;

\section{Table 2}

Basic statistics of the reinforced concrete pipes experiments

\begin{tabular}{|c|c|c|c|}
\hline $\begin{array}{c}\mathrm{DN} \\
(\mathrm{mm})\end{array}$ & Specimen & $\begin{array}{c}P_{\text {ult }} \\
(\mathrm{kN} / \mathrm{m})\end{array}$ & $\begin{array}{c}P_{\text {ser }} \\
(\mathrm{kN} / \mathrm{m})\end{array}$ \\
\hline \multirow{17}{*}{800} & 1 & 97.584 & 68.691 \\
\hline & 2 & 93.753 & 58.450 \\
\hline & 3 & 77.767 & 61.281 \\
\hline & 4 & 91.173 & 62.363 \\
\hline & 5 & 89.591 & 61.531 \\
\hline & 6 & 93.587 & 61.281 \\
\hline & 8 & 86.926 & 57.617 \\
\hline & 9 & 89.174 & 68.608 \\
\hline & 10 & 86.843 & 62.031 \\
\hline & 11 & 83.263 & 53.455 \\
\hline & 12 & 90.923 & 72.522 \\
\hline & 13 & 92.671 & 74.187 \\
\hline & 14 & 100.852 & 63.904 \\
\hline & 15 & 105.535 & 55.890 \\
\hline & 16 & 103.142 & 61.198 \\
\hline & Mean & 92.395 & 62.477 \\
\hline & Standard deviation & 7.211 & 5.892 \\
\hline \multirow{17}{*}{1200} & 1 & 132.387 & 86.593 \\
\hline & 2 & 133.303 & 96.668 \\
\hline & 3 & 131.805 & 92.837 \\
\hline & 4 & 133.387 & 86.093 \\
\hline & 5 & 131.222 & 94.669 \\
\hline & 6 & 123.561 & 97.917 \\
\hline & 8 & 128.557 & 78.017 \\
\hline & 9 & 134.719 & 93.087 \\
\hline & 10 & 137.883 & 90.673 \\
\hline & 11 & 141.879 & 98.333 \\
\hline & 12 & 142.795 & 99.082 \\
\hline & 13 & 137.883 & 89.091 \\
\hline & 14 & 141.858 & 57.763 \\
\hline & 15 & 139.881 & 56.723 \\
\hline & 16 & 132.596 & 63.800 \\
\hline & Mean & 135.557 & 84.358 \\
\hline & Standard deviation & 5.828 & 14.745 \\
\hline
\end{tabular}

S : sample standard deviation;

$\mathrm{n}$ : number of samples.

Thus, the $\mathrm{Cl}$ around the mean is given by:

$P\left(\bar{x}-t_{\alpha / 2, n-1} \frac{S}{\sqrt{n}} \leq \mu \leq \bar{x}+t_{\alpha / 2, n-1} \frac{S}{\sqrt{n}}\right)=1-\alpha$

being:

$\mathrm{P}$ : probability of the confidence interval to contain the mean;

$t_{\alpha / 2, n-1}$ : upper point $(100 \alpha / 2) \%$ of the Student $t$ distribution with $(n-1)$ degrees of freedom.

Another statistical inference technique is the application of hypothesis test, used to verify which of two competing affirmations about a parameter value is truthful [19]. In this paper, the hypothesis test is applied to evaluate if, for each pipe, there is meaningful statistical difference between the sample mean of $P_{\text {ult }}$ and $P_{\text {ser }}$ and its respective design values (DV). Thus, the null hypothesis $\left(\mathrm{H}_{0}\right)$ is that the sample mean is equal to the DV and the alternative hypothesis $\left(\mathrm{H}_{1}\right)$ is that the sample mean is greater than DV.

For the cases that the population follows Normal distribution, as the compressive strength resistance of the concrete [13,15], with unknown variance, the Student $t$ distribution with $(n-1)$ degrees of freedom is assumed as the statistical distribution [19], being this the procedure adopted in this paper. Then, the test statistics is given by:

$t_{\text {calc }}=\frac{\bar{x}-\mu_{1}}{\frac{S}{\sqrt{n}}}$

being:

$t_{\text {calc }}$ : test statistics with Student $t$ distribution and $(n-1)$ degrees of freedom;

$\mu_{1}$ : design value.

For a significance level $\alpha, \mathrm{H}_{0}$ must be rejected if the test statistics is greater than the critical value i.e.

$t_{\text {calc }}>t_{1-\alpha, n-1}$

otherwise, the null hypothesis cannot be rejected.

Another way to report the result of a hypothesis test is by means of the P-value probability, which is lower than $\alpha$ that leads $\mathrm{H}_{0}$ to rejection. Therefore, if the calculated $p$-value is lower than the significance level $\alpha$, the null hypothesis is rejected [19]. Statistical software can be employed to calculate P-value, such as the Past! [20], which was used in this paper.

\section{Table 3}

Confidence intervals (Cl) for $95 \%$ of confidence and design values (DV) of $\mathrm{P}_{\text {ult }}$ and $\mathrm{P}_{\text {ser }}$ in the reinforced concrete pipes calculated with specimen characteristic values

\begin{tabular}{ccc}
\hline $\begin{array}{c}\text { DN } \\
(\mathrm{mm})\end{array}$ & $\begin{array}{c}\mathbf{P}_{\text {ult }} \\
(\mathrm{kN} / \mathrm{m})\end{array}$ & $\begin{array}{c}\mathbf{P}_{\text {ser }} \\
(\mathrm{kN} / \mathrm{m})\end{array}$ \\
\hline \multirow{2}{*}{800} & IC: $[88.553-96.238]$ & IC: $[59.337-65.617]$ \\
& VP: 70.647 & VP: 24.796 \\
1200 & IC: $[132.451-138.662]$ & IC: $[76.501-92.215]$ \\
& VP: 80.085 & VP: 27.050 \\
\hline
\end{tabular}




\section{Table 4}

Hypothesis test for the mean values of $\mathrm{P}_{\mathrm{ult}}$ and $\mathrm{P}_{\text {ser }}(\alpha=5 \%$ and DV with characteristic values)

\begin{tabular}{|c|c|c|c|c|c|}
\hline \multirow{2}{*}{$\begin{array}{l}\text { DN } \\
(\mathrm{mm})\end{array}$} & \multirow{2}{*}{ Load } & \multicolumn{4}{|c|}{ Hypothesis test with $t_{0.95 ; 15}=1.753$} \\
\hline & & Hypothesis & $t_{\text {calc }}$ & Decision & P-value \\
\hline \multirow{2}{*}{800} & $\mathrm{P}_{\text {ult }}$ & $\begin{array}{l}\mathrm{H}_{0}: \mu=70.647 \mathrm{kN} / \mathrm{m} \\
\mathrm{H}_{1}: \mu>70.647 \mathrm{kN} / \mathrm{m}\end{array}$ & 12.065 & Reject $\mathrm{H}_{0}$ & $4.0 .10^{-9}$ \\
\hline & $P_{\text {ser }}$ & $\begin{array}{l}H_{0}: \mu=24.796 \mathrm{kN} / \mathrm{m} \\
H_{1}: \mu>24.796 \mathrm{kN} / \mathrm{m}\end{array}$ & 25.579 & Reject $\mathrm{H}_{0}$ & $8, .7 \cdot 10^{-14}$ \\
\hline \multirow{2}{*}{1200} & $\mathrm{P}_{\text {ult }}$ & $\begin{array}{l}H_{0}: \mu=80.085 \mathrm{kN} / \mathrm{m} \\
H_{1}: \mu>80.085 \mathrm{kN} / \mathrm{m}\end{array}$ & 38.074 & Reject $\mathrm{H}_{0}$ & $2.4 .10^{-16}$ \\
\hline & $P_{\text {ser }}$ & $\begin{array}{l}\mathrm{H}_{0}: \mu=27.050 \mathrm{kN} / \mathrm{m} \\
\mathrm{H}_{1}: \mu>27.050 \mathrm{kN} / \mathrm{m}\end{array}$ & 15.546 & Reject $\mathrm{H}_{0}$ & $1.2 .10^{-10}$ \\
\hline
\end{tabular}

\section{Results and discussions}

By applying the data in the Table 1 to equations (3), (11), (12), (13), (14) and (15), it is obtained the design values (DV) of the ultimate and service forces for the pipes with DN $800 \mathrm{~mm}$, respectively $70.647 \mathrm{kN} / \mathrm{m}$ and $24.796 \mathrm{kN} / \mathrm{m}$, and for the pipes with DN $1200 \mathrm{~mm}$, $80.085 \mathrm{kN} / \mathrm{m}$ and $27.050 \mathrm{kN} / \mathrm{m}$.

Basic statistics of the experiments of Silva [8] and Silva et al. [9] are presented in Table 2.

At confidence level $(1-\alpha)$ of $95 \%$, confidence intervals $(\mathrm{Cl})$ were obtained around the mean values of $\mathrm{P}_{\text {ult }}$ and $\mathrm{P}_{\text {ser }}$ shown in Table 3 , in which, for the sake of comparison, the respective design values (DV) are presented.

Since the design values of $\mathrm{P}_{\text {ult }}$ and $\mathrm{P}_{\text {ser }}$ for both pipes are below the lower limit of each $\mathrm{Cl}$, it is suspected that the ultimate and service forces are significantly greater than their respective DV. Indeed, the results of the hypothesis test for the mean values of $P_{\text {ult }}$ and $P_{\text {ser }}$, depicted in Table 4, confirm that suspicion.

In the four hypothesis test, the value of $t_{\text {calc }}$ is superior to the critical one of 1.753 , notably for $P_{\text {ser }}$ of DN800 and for $P_{\text {ult }}$ of DN1200. In other words, ultimate and service forces are significantly greater than their respective DV values. Note that the high values of $t_{\text {calc }}$ are due to the great difference between the sample mean and the DV as well as the low sample standard deviation.

Since the DV were obtained with the characteristic resistance values of materials, it can be suspected that the obtained differences are excessive. Then, the same tests were carried out using the mean resistance values of the materials, which is a condition that is more

\section{Table 5}

Confidence intervals (Cl) for $95 \%$ of confidence and design values (DV) of $\mathrm{P}_{\text {ult }}$ and $\mathrm{P}_{\text {ser }}$ in the reinforced concrete pipes calculated with specimen mean values

\begin{tabular}{ccc}
\hline $\begin{array}{c}\text { DN } \\
(\mathbf{m m})\end{array}$ & $\begin{array}{c}\mathbf{P}_{\text {ult }} \\
(\mathrm{kN} / \mathrm{m})\end{array}$ & $\begin{array}{c}\mathbf{P}_{\text {ser }} \\
(\mathrm{kN} / \mathrm{m})\end{array}$ \\
\hline \multirow{2}{*}{800} & IC: $[88.553-96.238]$ & IC: $[59.337-65.617]$ \\
& VP: 73.519 & VP: 28.401 \\
1200 & IC: $[132.451-138.662]$ & IC: $[76.501-92.215]$ \\
& VP: 82.627 & VP: 29.390 \\
\hline
\end{tabular}

close to the actual behaviour. The results are presented in Table 5 for the confidence intervals with confidence level $(1-\alpha)$ of $95 \%$ and in Table 6 for the hypothesis tests for the mean values of $\mathrm{P}_{\text {ult }}$ and $\mathrm{P}_{\text {ser }}$. Although the number of specimen tested by Silva [8] and Silva et al. [9] is not large, the obtained results may be considered valid. According to Mongomery and Runger [19], recent studies indicate that the Student $t$ test is relatively insensitive to the normality of the population, working satisfactorily with small samples. Thus, the hypothesis test results of this paper allow inferring, under a risk of $4 \times 10^{-7 \%}$ (maximum $p$-value obtained in the tests), that the reinforced concrete pipes tend to present a compression resistance way superior then the design estimates.

Such result evidences that the adopted design procedure for reinforced concrete pipes result in values very lower than the ones experimentally observed, which could result in oversized pipes.

\section{Table 6}

Hypothesis tests for the mean values of $\mathrm{P}_{\mathrm{ult}}$ and $\mathrm{P}_{\text {ser }}(\alpha=5 \%$ and DV with mean values)

\begin{tabular}{|c|c|c|c|c|c|}
\hline \multirow{2}{*}{$\begin{array}{c}\text { DN } \\
(\mathrm{mm})\end{array}$} & \multirow{2}{*}{ Load } & \multicolumn{4}{|c|}{ Hypothesis test with $t_{0.95 ; 15}=1.753$} \\
\hline & & Hypothesis & $t_{\text {calc }}$ & Decision & P-value \\
\hline \multirow{2}{*}{800} & $\mathrm{P}_{\text {ult }}$ & $\begin{array}{l}\mathrm{H}_{0}: \mu=73.519 \mathrm{kN} / \mathrm{m} \\
\mathrm{H}_{1}: \mu>73.519 \mathrm{kN} / \mathrm{m}\end{array}$ & 10.472 & Reject $\mathrm{H}_{0}$ & $2.7 .10^{-8}$ \\
\hline & $P_{\text {ser }}$ & $\begin{array}{l}H_{0}: \mu=28.401 \mathrm{kN} / \mathrm{m} \\
H_{1}: \mu>28.401 \mathrm{kN} / \mathrm{m}\end{array}$ & 23.132 & Reject $\mathrm{H}_{0}$ & $3.8 .10^{-13}$ \\
\hline \multirow{2}{*}{1200} & $P_{\text {ult }}$ & $\begin{array}{l}\mathrm{H}_{0}: \mu=82.627 \mathrm{kN} / \mathrm{m} \\
\mathrm{H}_{1}: \mu>82.627 \mathrm{kN} / \mathrm{m}\end{array}$ & 36.330 & Reject $\mathrm{H}_{0}$ & $4.9 .10^{-16}$ \\
\hline & $P_{\text {ser }}$ & $\begin{array}{l}\mathrm{H}_{0}: \mu=29.390 \mathrm{kN} / \mathrm{m} \\
\mathrm{H}_{1}: \mu>29.390 \mathrm{kN} / \mathrm{m}\end{array}$ & 14.911 & Reject $\mathrm{H}_{0}$ & . $1.10^{-10}$ \\
\hline
\end{tabular}


Table 7

Comparison of the hyperbolic and linear stress distributions [6]

\begin{tabular}{cccccc}
\hline Hyperbolic stress distribution & & \multicolumn{2}{c}{ Linear stress distribution } & $\begin{array}{c}\text { Error of S due } \\
\text { to linear stress } \\
\text { distribution }\end{array}$ \\
\hline$r_{m} / h$ & $\alpha$ & $\beta$ & $\alpha$ & $\beta$ & $\%$ \\
1 & 9.2 & -4.4 & 6.0 & -6.0 & 35.0 \\
2 & 14.4 & -10.3 & 12.0 & -12.0 & 17.0 \\
3 & 20.2 & -16.1 & 18.0 & -18.0 & 10.9 \\
4 & 26.2 & -22.2 & 24.0 & -24.0 & 9.2 \\
10 & 62.0 & -58.0 & 60.0 & -60.0 & 3.2 \\
\hline
\end{tabular}

Where: $\alpha=\frac{\frac{\sigma_{\max }}{M}}{A r_{m}}$ and $\beta=\frac{\frac{\sigma_{\min }}{M}}{A r_{m}}$ being $\mathrm{M}$ the bending moment, A the cross section area and $\mathrm{r}_{\mathrm{m}}$ the average radius of the pipe.

Then, it may be inferred that the current design model for reinforced concrete pipes, based on Euler-Bernoulli hypothesis, may be inadequate to pipes in which the ratio between the radius and the cross section height $\left(r_{m} / h\right)$ is lower than 10. In circular structures, such as arches and rings, composed by homogeneous materials with linear-elastic regime, Timoshenko [6] proves that the axial strains in the cross section are given by a hyperbolic equation. The simplification to the Euler-Bernoulli hypothesis (linear strain distribution) presents satisfactorily values if the ration $\mathrm{r}_{\mathrm{m}} / \mathrm{h}$ is greater than 10 , according to the comparison between stresses depicted by Timoshenko [6] and reproduced in Table 7 .

An alternative to enhance the design procedure of reinforced concrete pipes might be the consideration of the hyperbolic strains [6] in the cross section, instead of the linear ones.

\section{Conclusions}

The adoption of Euler-Bernoulli hypothesis for reinforced concrete pipes leads to resistance values lower than the ones experimentally observed, according to the analysis presented in this paper from the experiments of Silva [8] and Silva et al. [9]. However, it is necessary to carry on an extensive experimental campaign with a greater sample in order to corroborate the observations of this paper.

If these results are then confirmed, a design procedure may be proposed specifically for this type of structure, which would lead to modification in NBR 8890 [4] and NBR 6118 [5].

Naturally, such development must take into account extensive experimental researches in order to ensure that the design procedure approximates the actual structural behaviour.

\section{Acknowledgements}

The authors acknowledge the Post-Graduation Program in Civil Engineering of Federal University of Sergipe for the physical support.

\section{References}

[1] BECK, A. T. Curso de confiabilidade estrutural, Notas de aula (SET 5915 - Confiabilidade Estrutural), EESC/USP, 2012.
[2] EL DEBS, M. K. Projeto estrutural de tubos de concreto armado, IBTS, 2003.

[3] ZAIDLER, W. Projetos estruturais de tubos enterrados. PINI, 1983.

[4] ASSOCIAÇÃO BRASILEIRA DE NORMAS TÉCNICAS. NBR 8890: Tubo de concreto de seção circular para águas pluviais e esgotos sanitários - requisitos e métodos de ensaios. Rio de Janeiro, 2008.

[5] ASSOCIAÇÃO BRASILEIRA DE NORMAS TÉCNICAS. NBR 6118: Projeto de estruturas de concreto armado procedimento. Rio de Janeiro, 2014.

[6] TIMOSHENKO, S. P. Resistência dos Materiais: volume 1, Ao Livro Técnico S.A., 1967.

[7] THOFT-CHRISTENSEN, P.; BAKER, M. J. Structural Reliability Theory and Its Applications, Springer-Verlag, 1982.

[8] SILVA, J. L. Análise de tubos circulares de concreto armado para o ensaio de compressão diametral com base na teoria de confiabilidade, São Carlos, 2011, Tese (doutorado), Escola de Engenharia de São Carlos, Universidade de São Paulo, $172 \mathrm{p}$.

[9] SILVA, J. L.; EL DEBS, M. K.; KATAOKA, M. N. A comparative experimental investigation of reinforced-concrete pipes under three-edge-bearing test: Spigot and Pocket and Ogee Joint pipes. Acta Scientiarum Technology. V. 40, e30860, 2018.

[10] SILVA, J. L.; EL DEBS, M. K.; BECK, A. T. Análise da confiabilidade de tubos de concreto armado no estado limite de fissuração, Revista IBRACON de Estruturas e Materiais, v. 1, n. 4, p. 314-330, 2008.

[11] FIGUEIREDO, A. D.; DE LA FUENTE, A.; AGUADO, A.; MOLINS, C.; CHAMA NETO, P. J. Tubos de concreto reforçado com fibras de aço. Parte 1: análise tecnológica do comportamento mecânico, Revista IBRACON de Estruturas e Materiais, v. 5, n. 1, p. 1-11, 2012.

[12] OLIVEIRA, M. A. B.; MACÊDO, A. N.; POMPEU, B. B.; CABRAL, A. E. B. Tubos de concreto produzidos com fibras de aço e agregados da região metropolitana de Belém do Pará, Ambiente Construído, v. 17, n. 4, p. 141-163, 2017.

[13] ARAÚJO, J. M. Curso de concreto armado: volume 1. Rio Grande: Dunas, 2014a. 
[14] ARAÚJO, J. M. Curso de concreto armado: volume 3. Rio Grande: Dunas, 2014b.

[15] CARVALHO, R. C.; FIGUEIREDO FILHO, J. R. Cálculo e Detalhamento de Estruturas Usuais de Concreto Armado: segundo a NBR 6118:2014. EdUFSCar, 2015.

[16] CARVALHO, R. C.; PINHEIRO, L. M. Cálculo e detalhamento de estruturas de concreto armado: volume 2. PINI, 2013.

[17] FUSCO, P. B. Estruturas de concreto: solicitações normais. Guanabara Dois, 1981.

[18] GIONGO, J. S. Concreto armado: análises das resistências das seções transversais de elementos estruturais, Notas de aula (SET 409 - Estruturas de Concreto Armado I), EESC/USP, 2015.

[19] MONTGOMERY, D. C.; RUNGER, G. C. Estatística Aplicada e Probabilidade para Engenheiros. Rio de Janeiro: LTC, 2018.

[20] HAMMER, $\varnothing$;; HARPER, D. A. T.; RYAN, P. D. PAST: Paleontological Statistics Software Package for Education and Data Analysis, Palaeontologia Electronica, v. 4, n. 1, p. 1-31, 2001. 